\title{
SISTEM SELEKSI PENERIMAAN SISWA BARU BERDASARKAN CABANG OLAHRAGA DENGAN MENGGUNAKAN METODE PROMETHEE
}

\author{
${ }^{1)}$ Lagut Hamulian, ${ }^{2)}$ Agustin \\ ${ }^{1,2)}$ Teknik Informatika, Teknologi Informasi, STMIK-Amik Riau \\ ${ }^{1,2} \mathrm{Jl}$. Purwodadi Indah, Panam, Pekanbaru - Riau - Indonesia \\ E-mail : laguthamulian@gmail.com,agustin@sar.ac.id
}

\begin{abstract}
ABSTRAK
Sekolah Menengah Atas Negeri Olahraga merupakan satu-satunya sekolah tingkat menengah yang mewadahi penyaluran minat dan bakat siswa-siswi di bidang olahraga. SMA Negeri Olahraga memiliki kriteria-kriteria khusus untuk menentukan siswa yang berhak masuk ke SMA tersebut. Kriteria tersebut digunakan untuk menentukan cabang olahraga yang cocok bagi siswa berdasarkan kemampuan yang dimiliki. Sistem yang ada selama ini belum bisa menyeleksi siswa sesuai dengan kemampuannya, sehingga siswa tidak diterima dan tidak dapat mengasah lebih lanjut bakat dan keahlian yang dimiliki. Untuk itu diperlukan sebuah sistem yang otomatis mampu menyeleksi siswa berdasarkan kriteria sesuai dengan kemampuannya. Sistem dirancang menggunakan metode promethee. Metode Promethee menggunakan kriteria dan bobot yang kemudian diolah untuk menentukan pemilihan alternative cabang olahraga, yang hasilnya berurutan berdasarkan prioritasnya. Hasil penelitian, metode ini dapat mengurutkan siswa berdasarkan kemampuan yang mereka miliki disetiap cabang olahraga. Hal ini membantu pihak sekolah dalam menyeleksi dan menentukan cabang olahraga yang cocok bagi siswa baru.
\end{abstract}

Kata Kunci: Sistem Seleksi, Metode Promethee, Web

\begin{abstract}
Senior High School of Sports is the only secondary school that facilitates channeling the interests and talents of students in the field of sports. SMA Negeri Sports has special criteria to determine students who are entitled to enter the high school. These criteria are used to determine the sport that is suitable for students based on their abilities. The existing system has not been able to select students according to their abilities, so students are not accepted and cannot further hone their talents and expertise. For that we need a system that is automatically able to select students based on criteria according to their abilities. The system is designed using the Promethe method. The Promethee method uses criteria and weights which are then processed to determine alternative sport branches, the results of which are sequentially based on their priorities. The results of this study, this method can sort students based on their abilities in each branch of sport. This helps the school select and determine the sport that is suitable for new students.
\end{abstract}

Keyword: Selection System, Promethee Method, Web

\section{PENDAHULUAN}

Sekolah Menengah Atas Negeri Olahraga merupakan sekolah tingkat menengah yang mewadahi penyaluran minat dan bakat siswa di bidang olahraga. Di Riau sendiri hanya ada satu sekolah tingkat menengah di bidang olahraga, yaitu SMA Negeri Olahraga. Banyak siswa yang memiliki bakat dibidang olahraga yang telah lulus dari sekolah menengah tingkat pertama (SMP) berkeinginan masuk ke SMA Negeri Olahraga. SMA Negeri Olahraga memiliki kriteria-kriteria khusus untuk menentukan siswa yang berhak masuk ke SMA tersebut. Kriteria tersebut digunakan untuk menentukan cabang olahraga yang cocok bagi siswa berdasarkan kriteria yang dipenuhinya. Kriteria-kriterianya meliputi kondisi fisik, teknik yang dikuasai dan mental yang dimiliki siswa.

Sistem yang ada selama ini belum bisa menyeleksi siswa sesuai dengan kemampuannya, sehingga siswa tidak diterima dan tidak dapat mengasah lebih lanjut bakat, kemampuan dan keahlian yang dimiliki.

Menyelesaikan masalah tersebut, SMA Negeri Olahraga memerlukan sebuah sistem yang otomatis mampu menyeleksi siswa berdasarkan kriteria sesuai dengan kemampuannya

Sehingga dengan adanya sistem ini, mampu memberi kemudahan kepada pihak sekolah untuk menentukan cabang olahraga yang pas untuk siswa baru, memberikan 
kemudahan dalam meningkatkan sistem penyeleksian cabang olahraga dan memberikan kemudahan siswa untuk mengetahui cabang olahraga yang sesuai dengan kemauan dan kemampuan yang dimiliki.

Penelitian sebelumnya tentang metode promethee sudah dilakukan oleh Yuwono at all pada Tahun 2011 dengan judul penelitian Sistem Pendukung Keputusan Menggunakan Metode Promethee (Studi Kasus : Stasiun Pengisian Bahan Bakar Umum). Penelitian ini menghasilkan sebuah sistem yang dapat menentukan lokasi pendirian stasiun pengisian bahan bakar umum menggunakan metode promethee. Penelitian tentang metode promethee juga pernah dilakukan oleh Taufik at all Tahun 2017 dengan judul penelitian Implementasi Metode Promethee Untuk Menentukan Penerima Beasiswa. Hasil penelitian ini adalah menerapkan metode Promethee untuk rekomendasi pilihan kandidat penerima beasiswa per jurusan berdasarkan kriteria-kriteria yang diberikan. Penelitian lain juga telah dilakukan oleh safrizal dan Lili Tanti, Tahun 2015. Judul penelitiannya adalah Penerapan Metode Promethee Dalam Penyeleksian Siswa Baru (Airlines Staff) Pada LPP Penerbangan. Hasil penelitiannya adalah metode promethee dapat memberikan rekomendasi dalam pengambilan keputusan penerimaan siswa baru dan penempatan siswa pada perusahaan penerbangan

\section{METODE}

\section{Metode Promethee}

Promethee adalah metode penentuan urutan atau prioritas dalam analisis multikriteria. Metode ini lebih simpel, lebih efisien dan lebih mudah diterapkan dibanding dengan metode analisis multikriteria lainnya. Metode ini mampu mengakomodir kriteria pemilihan yang bersifat kualitatif dan kuantitatif [4]. Masalah utamanya adalah kesederhanaan, kejelasan dan kestabilan. Dominasi kriteria yang digunakan dalam Promethee adalah penggunaan nilai dalam hubungan outranking [5].

Metode promethee memiliki enam tipe fungsi preferensi kriteria. Memberikan gambaran yang lebih baik terhadap area yang tidak sama, digunakan fungsi selisih nilai kriteria antara alternative $\mathrm{H}(\mathrm{d})$ dimana hal ini mempunyai hubungan langsung pada fungsi preferensi $\mathrm{P}[1]$.

Penelitian ini yang menggunakan tipe preferensi tipe 3 atau linear. Selama nilai selisih memiliki nilai lebih rendah dari $p$, maka preferensi dari (d) pembuat keputusan meningkat secara linier dengan nilai d. Jika nilai d lebih besar dibandingkan dengan nilai p, maka terjadi preferensi mutlak.

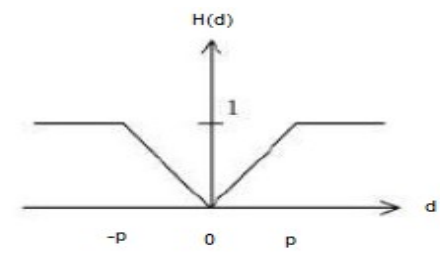

Gambar 1. Kriteria dengan preferensi linier

Keterangan:

1. H (d): fungsi selisih kriteria antar alternatif

2. P: nilai kecenderungan

3. Parameter $(q)$ : harus merupakan nilai tetap Berikut ke enam tipe preferensi[6]:

Tabel 1. Tipe Fungsi Preferensi Kriteria

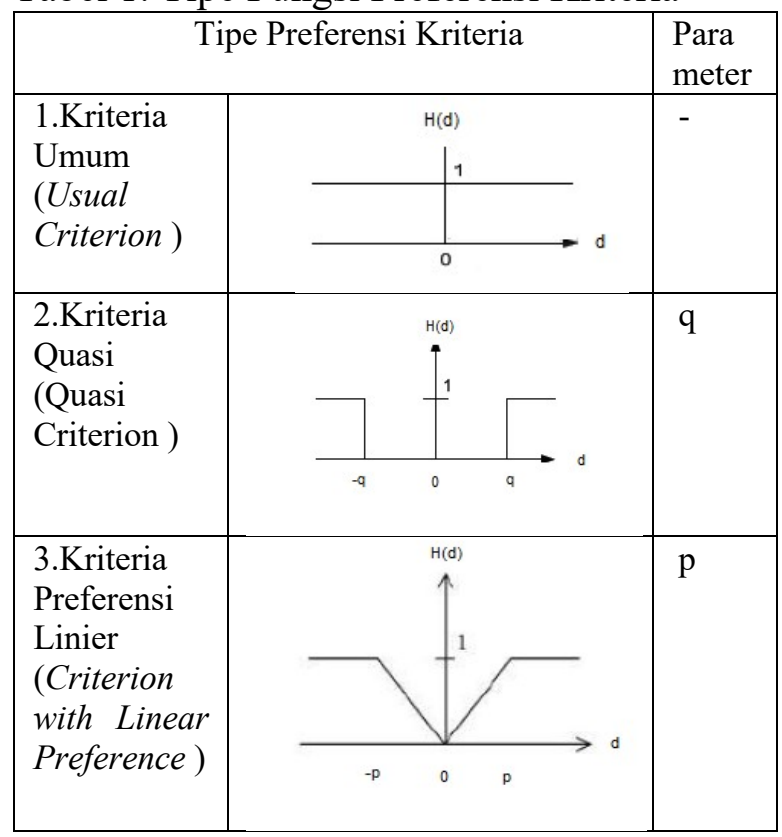




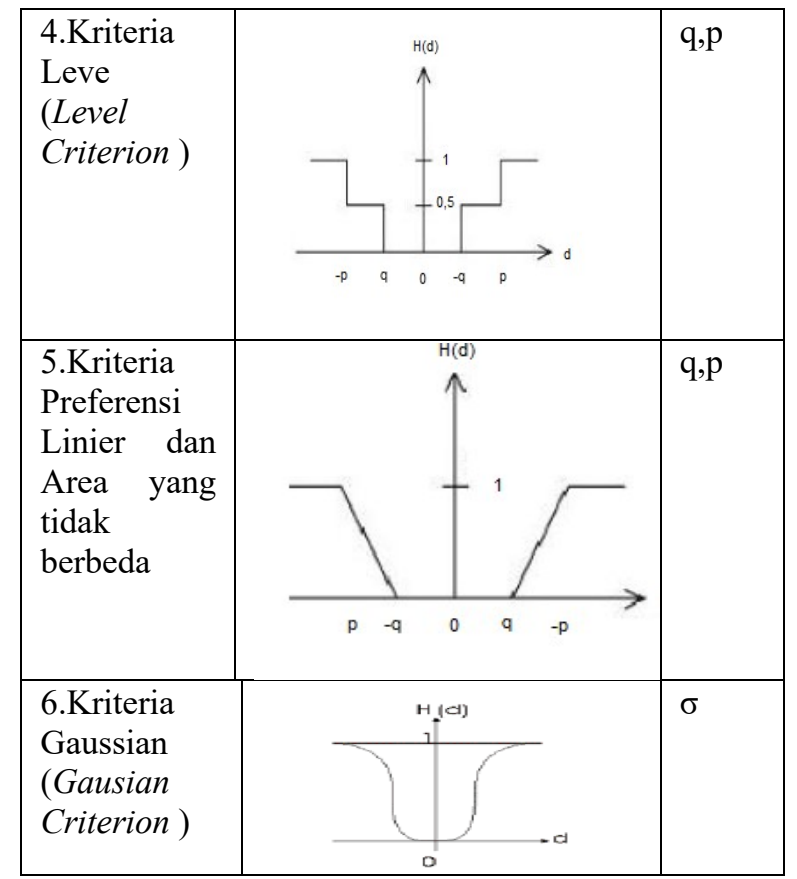

Langkah-langkah metode Promethee sebagai berikut:

1. Menentukan beberapa alternatif

2. Menentukan beberapa kriteria

3. Menentukan dominasi kriteria

4. Menentukan tipe preferensi untuk setiap kriteria yang paling cocok yang didasarkan pada data dan pertimbangan dari decision maker.

5. Memberikan nilai threshold setiap kriteria berdasarkan preferensi yang telah dipilih.

6. Perhitungan Entering flow, Leaving flow dan Net flow

7. Pengurutan hasil dari perangkingan

\section{Metodologi Penelitian}

Mempermudah dalam pengerjaan penelitian dibuatlah kerangka kerja penelitian seperti pada gambar 2 dibawah ini:

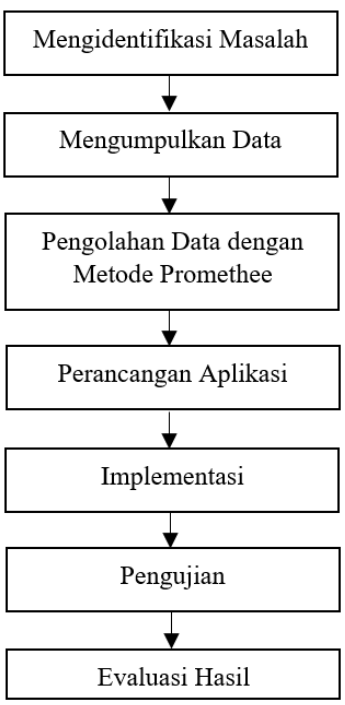

Gambar 2. Kerangka Kerja Penelitian

Berdasarkan kerangka kerja yang ada pada gambar 2 diatas, masing-masing tahapan tersebut dapat dijelaskan sebagai berikut :

a. Mengidentifikasi Masalah

Tahap ini dilakukan identifikasi masalah yang diteliti untuk mengkaji lebih dalam tentang permasalahan yang ada.

b. Mengumpulkan Data

Pada tahapan ini dilakukan pengumpulan data terhadap sistem yang akan diteliti.

c. Pengolahan Data dengan Metode

Promethee

Data yang sudah diperoleh selanjutnya diolah menggunakan Metode Promethee dengan tahapan-tahapan dari metode tersebut. d. Perancangan Aplikasi

Pada tahap ini dilakukan proses perancangan sistem dengan menggunakan bahasa pemrograman $P H P$.

e. Implementasi

Tahap ini dilakukan implementasi Metode Promethee terhadap sistem yang sudah dirancang, untuk menyeleksi siswa baru.

f. Pengujian

Tahap ini dilakukan pengujian terhadap sistem yang telah dirancang. Pengujian dilakukan terhadap data siswa yang akan diseleksi.

g. Evaluasi Hasil

Penyeleksian siswa baru yang dihasilkan oleh pengolahan data menggunakan Metode promethee kemudian dievaluasi, dan hasil evaluasi ini bisa dijadikan sebagai bahan 
pengambilan kebijakan bagi pihak sekolah.

\section{HASIL}

\section{Analisa Metode Promethee}

Langkah-langkah yang dilakukan dalam penyelesaian masalah dengan metode promethee, sebagai berikut:

1. Menentukan beberapa alternatif

Pada langkah ini akan ditentukan beberapa alternatif dalam hal ini adalah beberapa siswa, yang berfungsi untuk dibandingkan dari satu alternatif dengan alternatif lainnya.

Tabel 2. Tabel Alternatif

\begin{tabular}{cl}
\hline No & Alternatif \\
\hline 1 & Gugun anggara \\
\hline 2 & Roni andira \\
\hline 3 & Bagas Mawahana \\
\hline 4 & Raihan Ilham Azhar \\
\hline
\end{tabular}

2. Menentukan kriteria

Pada sistem ini digunakan empat kriteria untuk melakukan perhitungan, yaitu :

Tabel 3. Tabel Kriteria

\begin{tabular}{ll}
\hline No & Kriteria \\
\hline 1 & Tes Fisik \\
\hline 2 & Tes Kesehatan \\
\hline 3 & Tes Kecepatan \\
\hline 4 & Tes Cabor \\
\hline
\end{tabular}

Menentukan nilai Leaving Flow , Entering Flow dan Net Flow, terdapat beberapa langkah, diantaranya adalah sebagai berikut :

a. Menghitung IP(Index Preference)

Nilai IP ini didapat dengan memabandingkan jarak nilai setiap alternatif
3. Menentukan dominasi atau bobot kriteria

Pada langkah ini diberikan nilai bobot pada masing-masing kriteria, dimana total dari bobot tersebut haruslah bernilai 1 .

Tabel 4. Tabel Bobot

\begin{tabular}{ll}
\hline Kriteria & Bobot \\
\hline Tes Fisik & 0.2 \\
\hline Tes Kesehatan & 0.2 \\
\hline Tes Kecepatan & 0.1 \\
\hline Tes Cabor & 0.5 \\
\hline Total Bobot & 1 \\
\hline
\end{tabular}

4. Menentukan tipe preferensi dan nilai parameter

Pada perhitungan ini, digunakan tipe preferensi tipe 3 atau linear. Dengan nilai parameter $p=20$.

Tabel 5. Tabel tipe preferensi dan nilai parameter

\begin{tabular}{lll}
\hline Kriteria & $\begin{array}{l}\text { Tipe } \\
\text { Preferensi }\end{array}$ & Parameter \\
\hline Tes Fisik & 3 & 20 \\
\hline Tes Kesehatan & 3 & 20 \\
\hline Tes Kecepatan & 3 & 20 \\
\hline Tes Cabor & 3 & 20 \\
\hline
\end{tabular}

5. Perhitungan Leaving Flow, Entering Flow dan Net Flow.

dengan alternatif lainnya. Kemudian dihitung dengan ketentuan :

$$
P\left\{\begin{array}{l}
d / p \text { jika }-p \leq d \leq p \\
p=1 \text { jika } d<-p \text { atau } d>p
\end{array}\right.
$$

Tabel 6. Nilai IP

\begin{tabular}{llllllll} 
Alternatif 1 & Alternatif 2 & A & B & D & $\mid$ D & P & IP \\
\hline Gugun Anggara & Roni Andira & 80 & 60 & 20 & 20 & 1 & 0.2 \\
\hline Gugun Anggara & Bagas Mawahana & 80 & 90 & -10 & 10 & -0.5 & -0.1 \\
\hline Gugun Anggara & Raihan Ilham A. & 80 & 90 & -10 & 10 & -0.5 & -0.1 \\
\hline Roni Andira & Gugun Anggara & 60 & 80 & -20 & 20 & -1 & -0.2 \\
\hline Roni Andira & Bagas Mawahana & 60 & 90 & -30 & 30 & 1 & 0.2 \\
\hline Roni Andira & Raihan Ilham A. & 60 & 90 & -30 & 30 & 1 & 0.2 \\
\hline Bagas Mawahana & Gugun Anggara & 90 & 80 & 10 & 10 & 0.5 & 0.1 \\
\hline
\end{tabular}




\begin{tabular}{llllllll}
\hline Bagas Mawahana & Roni Andira & 90 & 60 & 30 & 30 & 1 & 0.2 \\
\hline Bagas Mawahana & Raihan Ilham A. & 90 & 90 & 0 & 0 & 0 & 0 \\
\hline Raihan Ilham A. & Gugun Anggara & 90 & 80 & 10 & 10 & 0.5 & 0.1 \\
\hline Raihan Ilham A. & Roni Andira & 90 & 60 & 30 & 30 & 1 & 0.2 \\
\hline Raihan Ilham A. & Bagas Mawahana & 90 & 90 & 0 & 0 & 0 & 0 \\
\hline
\end{tabular}

b. Menghitung Total IP(Index Preference)

Nilai Total IP ini didapat dengan cara menjumlahkan setiap nilai IP dari langkah sebelumnya disetiap kombinasi alternatif.

c. Menghitung Leaving dan Entering

Nilai Leaving didapat dengan cara menjumlahkan nilai IP setiap alternatif pertama yang sama, kemudian dibagi jumlah alternatif dan dikurang 1. Sedangkan untuk mencari nilai Entering adalah dengan cara menjumlahkan nilai IP setiap alternatif kedua yang sama, kemudian dibagi jumlah alternatif dan dikurang 1.

Tabel 7.Tabel Leaving dan Entering

\begin{tabular}{lllllll}
\hline Alternatif & $\begin{array}{l}\text { Gugun } \\
\text { Anggara }\end{array}$ & $\begin{array}{l}\text { Roni } \\
\text { Andira }\end{array}$ & $\begin{array}{l}\text { Bagas } \\
\text { Mawahana }\end{array}$ & $\begin{array}{l}\text { Raihan } \\
\text { Ilham } \\
\text { Azhar }\end{array}$ & Jumlah & Leaving \\
\hline Gugun Anggara & 0 & 0.58125 & 0.0625 & 0.3625 & $\mathbf{1 . 0 0 6 2 5}$ & $\mathbf{0 . 3 3 5 4 2}$ \\
\hline Roni Andira & -0.38125 & 0 & -0.04375 & 0.2563 & $\mathbf{- 0 . 1 6 8 8}$ & $\mathbf{- 0 . 0 5 6 3}$ \\
\hline Bagas Mawahana & 0.3375 & 0.84375 & 0 & 0.7 & $\mathbf{1 . 8 8 1 2}$ & $\mathbf{0 . 6 2 7 0 8}$ \\
\hline $\begin{array}{l}\text { Raihan Ilham } \\
\text { Azhar }\end{array}$ & -0.3625 & 0.14375 & -0.3 & 0 & $\mathbf{- 0 . 5 1 8 8}$ & $\mathbf{- 0 . 1 7 2 9}$ \\
\hline \multicolumn{1}{c}{ Jumlah } & $\mathbf{- 0 . 4 0 6 2 5}$ & $\mathbf{1 . 5 6 8 7 5}$ & $\mathbf{- 0 . 2 8 1 2 5}$ & $\mathbf{1 . 3 1 8 8}$ & & \\
\hline \multicolumn{1}{c}{ Entering } & $\mathbf{- 0 . 1 3 5 4 1}$ & $\mathbf{0 . 5 2 2 9 1 6}$ & $\mathbf{- 0 . 0 9 3 7 5}$ & $\mathbf{0 . 4 3 9 6}$ & & \\
\hline
\end{tabular}

d. Menghitung Leaving Flow, Entering Flow dan Net Flow.

Langkah terakhir adalah dengan menentukan nilai dari Leaving Flow, Entering Flow dan Net Flow. Dimana untuk menentukan leaving flow dan entering flow adalah dengan mengambil nilai dari langkah sebelumnya. Kemudian untuk menentukan nilai net flow adalah dengan mengurangkan nilai leaving flow dengan net flow. Semakin tinggi nilai net flow tersebut, maka semakin tinggi kecocokan alternatif tersebut.

Tabel 8. Tabel Leaving Flow, Entering Flow dan Net Flow

\begin{tabular}{lllll}
\hline Alternatif & Leaving Flow & Entering Flow & Net Flow & Urutan \\
\hline Gugun Anggara & 0.627083333 & -0.09375 & 0.720833333 & 1 \\
\hline Roni Andira & 0.335416667 & -0.135416667 & 0.470833333 & 2 \\
\hline Bagas Mawahana & -0.17291667 & 0.439583333 & -0.6125 & 3 \\
\hline Raihan Ilham Azhar & -0.05625 & 0.522916667 & -0.579166667 & 4 \\
\hline
\end{tabular}

Dari tabel di atas, Gugun Anggara menempati urutan pertama dengan nilai Net Flow 0.72 . dan Raihan Ilham Azhar menempati urutan ke 4. Namun pada penelitian ini, urutan 1 sampai 10 akan dianggap lolos seleksi. Dan urutan 10 kebawah akan dinyatakan tidak lolos.

\section{Implementasi Metode Promethee}

Implementasi metode promethee dilakukan terhadap data siswa yang mengikuti test cabang olahraga sepakbola adalah sebagai berikut: 
RABIT : Jurnal Teknologi dan Sistem Informasi Univrab

Volume 5 No. 2 | Juli 2020 : Hal :67-75

Tabel 9.Tabel Data Siswa

\begin{tabular}{lrlc}
\hline No & Nis & Nama & Umur \\
\hline 1 & 3251 & Gugun anggara & 17 \\
\hline 2 & 0765 & Roni andira & 17 \\
\hline 3 & 3542 & Bagas Mawahana & 16 \\
\hline 4 & 2234 & Raihan Ilham Azhar & 16 \\
\hline 5 & 2231 & Farid Isroq & 16 \\
\hline
\end{tabular}

\begin{tabular}{llll}
\hline 6 & 5544 & Farhan Shadiq & 16 \\
\hline 7 & 2227 & Raju & 16 \\
\hline 8 & 0967 & Ramanda & 16 \\
\hline 9 & 4323 & Muhammad dimas & 16 \\
\hline 10 & 3432 & M. Daniel & 16 \\
\hline 11 & 3456 & Sultan Saidi & 16 \\
\hline 12 & 4323 & Muhammad Raihan & 16 \\
\hline
\end{tabular}

Setelah dilakukan proses seleksi dengan menggunakan metode Promethee, maka didapat hasil sebagai berikut :

Tabel 10. Tabel Hasil Seleksi

\begin{tabular}{llccc}
\hline No & NAMA & Nilai Net Flow & Urutan & Ket \\
\hline 1 & Gugun Anggara & 0.72 & 1 & Lulus \\
\hline 2 & Roni Andira & 0.47 & 3 & Lulus \\
\hline 3 & Bagas Mawahana & -0.61 & 10 & Lulus \\
\hline 4 & Raihan Ilham Azhar & -0.58 & 9 & Lulus \\
\hline 5 & Farid Isroq & 0.49 & 2 & Lulus \\
\hline 6 & Farhan Shadiq & -0.62 & 11 & Tidak Lulus \\
\hline 7 & Raju & 0.35 & 6 & Lulus \\
\hline 8 & Ramanda & -0.31 & 7 & Lulus \\
\hline 9 & Muhammad Dimas & 0.45 & 4 & Lulus \\
\hline 10 & M. Daniel & -0.62 & 12 & Tidak Lulus \\
\hline 11 & Sultan Saidi & 0.35 & 5 & Lulus \\
\hline 12 & Muhammad Raihan & -0.31 & 8 & Lulus \\
\hline
\end{tabular}

\section{Perancangan Sistem}

Pada tahap ini dilakukan perancang sistem menggunakan Unified Modelling Language (UML) berdasarkan kebutuhan sistem oleh pihak sekolah

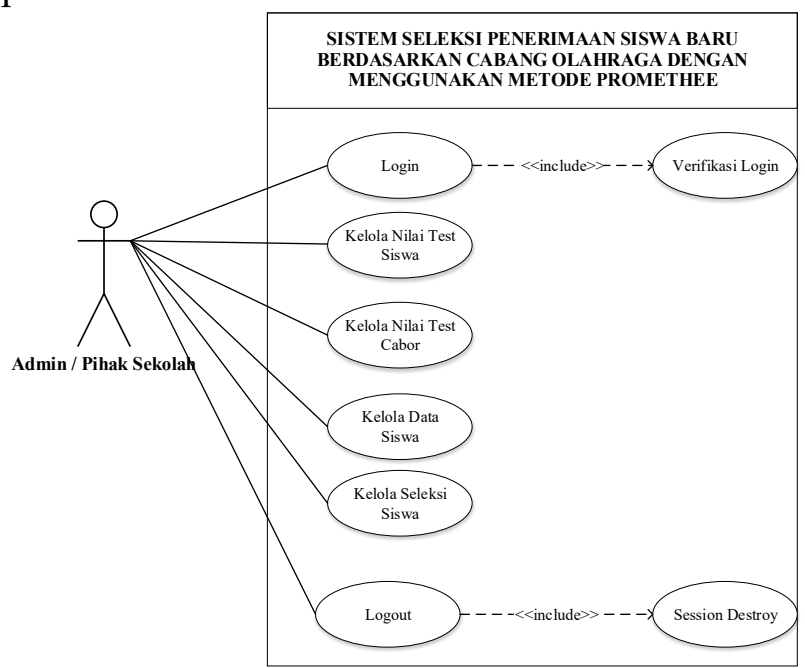

Gambar 3. Usecase Diagram

Gambar 3 diatas merupakan usecase diagram yang menggambarkan kegiatan actor terhadap sistem. Actor disini adalah pihak sekolah yang akan memakai sistem.

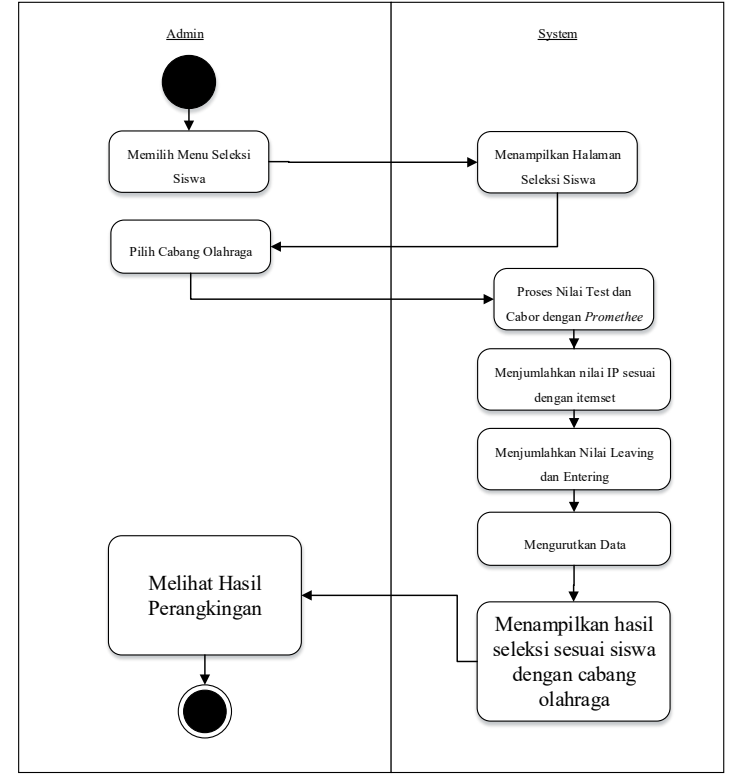

Gambar 4. Perancangan Activity Diagram Seleksi Siswa

Gambar 4 diatas merupakan activity diagram seleksi siswa. Admin memilih menu seleksi siswa, lalu sistem akan menampilkan halaman seleksi siswa tersebut. Kemudian admin akan memilih cabang olahraga yang 
ingin dirangking. Selanjutnya sistem akan memproses perangkingan siswa menggunakan metode Promethee berdasarkan cabang olahraga yang dipilih. Pertama sistem akan menjumlahkan semua nilai IP dalam itemset yang ada, setelah jumlah setiap IP didapat, maka sistem akan menjumlahkan kembali nilai leaving dan entering. Dari nilai tersebutlah nantinya sistem dapat merangking data siswa berdasarkan cabang olahraga yang dipilih.

\section{Implementasi Sistem}

Hasil Implementasi merupakan tampilan dari sistem seleksi penerimaan siswa baru sebagai berikut :

1. Tampilan Halaman Utama Sistem

Halaman utama sistem merupakan interface awal saat membuka sistem. Pada halaman ini terdapat form login admin yang berfungsi untuk memberikan izin kepada pengguna yang terdaftar pada sistem untuk dapat mengakses penggunaan sistem. Dimana pada form login tersebut membutuhkan inputan berupa username dan password.

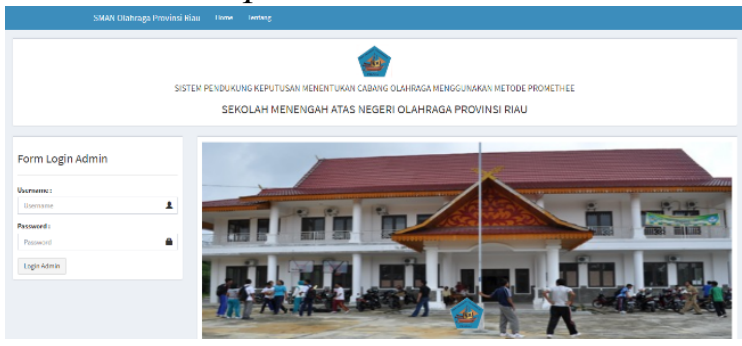

Gambar 5. Halaman Utama Sistem

2. Tampilan Halaman Menu Admin

Halaman admin merupakan halaman bekerja admin terkait sistem.

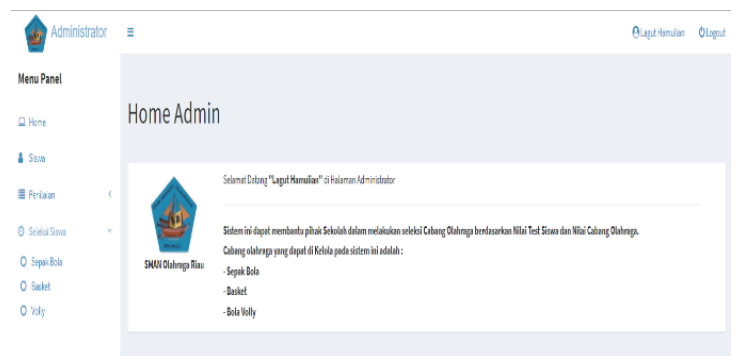

Gambar 6. Halaman Menu Admin

3. Tampilan Halaman Input Nilai Test Siswa

Halaman ini merupakan halaman menginputkan nilai test siswa.

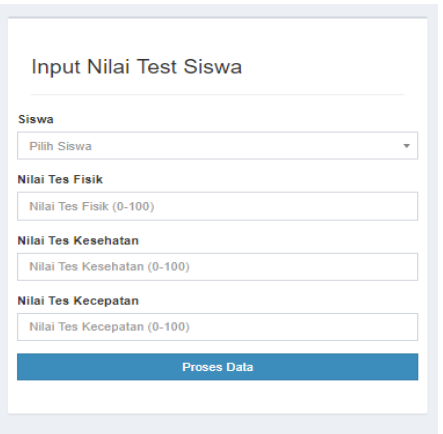

Gambar 7. Halaman Input Nilai Test Siswa

4. Tampilan Laporan Nilai Test Siswa

Tampilan ini merupakan halaman nilai hasil tes siswa

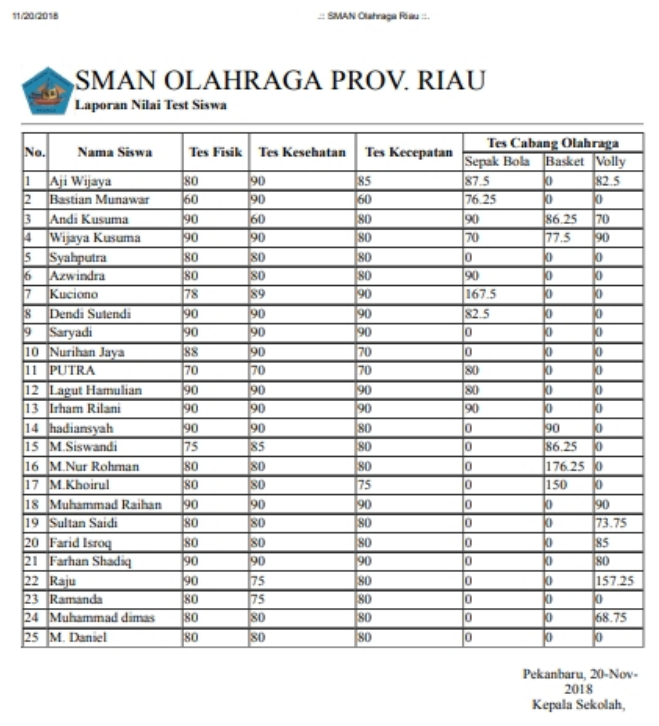

Gambar 8. Halaman Laporan Nilai Test Siswa

5. Tampilan Halaman Penilaian Cabor

Tampilan ini merupakan halaman penilaian terhadap masing-masing cabang olahraga, sesuai dengan tes yang diikuti oleh siswa. Admin dapat langsung menginputkan data nilai sesuai dengan cabang olahraga yang diikuti siswa, seperti sepak bola, basket dan bola voli. Setiap cabang olahraga memiliki atribut penilaian yang berbeda-beda. 


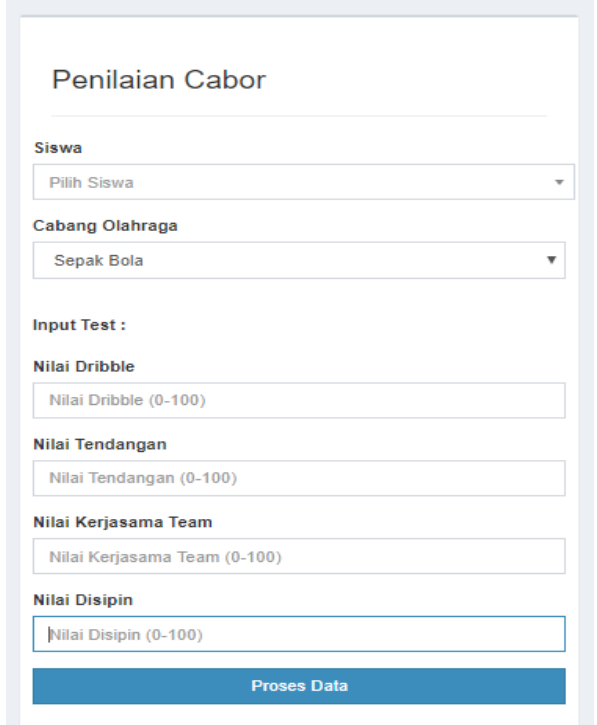

Gambar 9. Halaman Penilaian Cabor

\section{Tampilan Halaman Hasil Seleksi}

Tampilan ini merupakan halaman hasil akhir seleksi cabang olahraga sepak bola, basket ataupun voli. Tampilan ini memperlihatkan hasil keputusan menggunakan metode promethee. Pada hasil ini, semakin tinggi nilai Net Flow, maka siswa tersebut memilki potensi yang baik pada cabang olahraga yang dipilihnya.

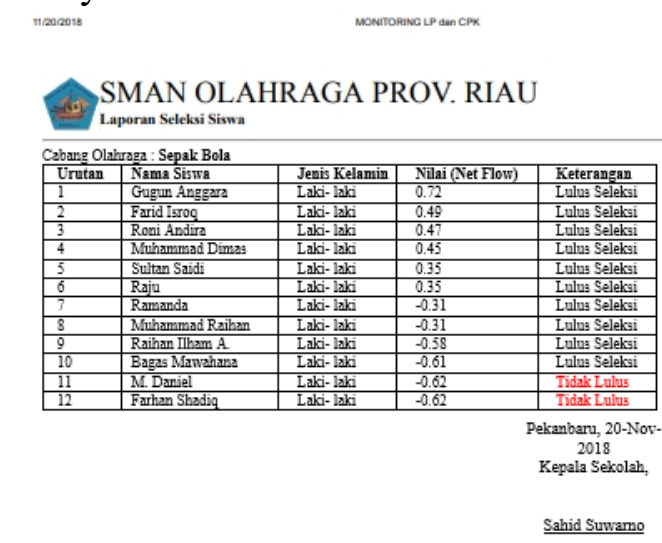

Gambar 10. Halaman Hasil Seleksi Sepak Bola

Tampilan gambar 10 diatas merupakan tampilan halaman hasil akhir seleksi cabang olahraga sepak bola, berdasarkan dari nilai siswa pada cabor sepak bola.

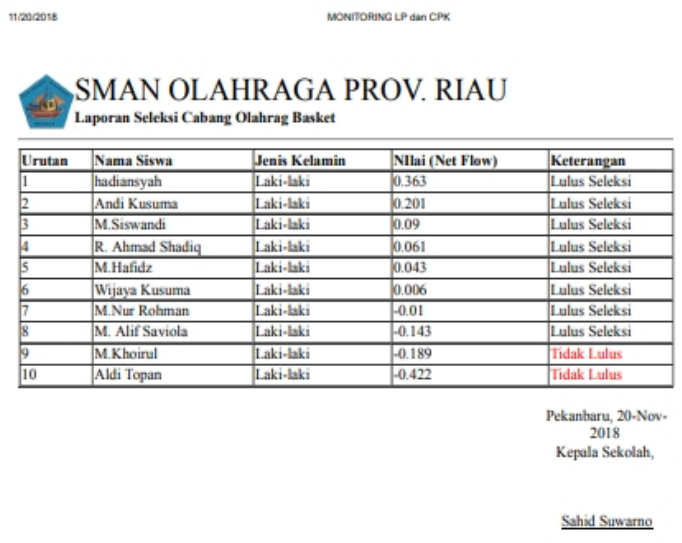

Gambar 11. Halaman Hasil Seleksi Basket

Gambar 11 merupakan halaman hasil akhir seleksi cabang olahraga basket, berdasarkan dari nilai siswa cabor basket. Jadi jika ada siswa yang tidak mengikuti test cabang olahraga basket, maka siswa tersebut tidak akan ditampilkan pada halaman ini.

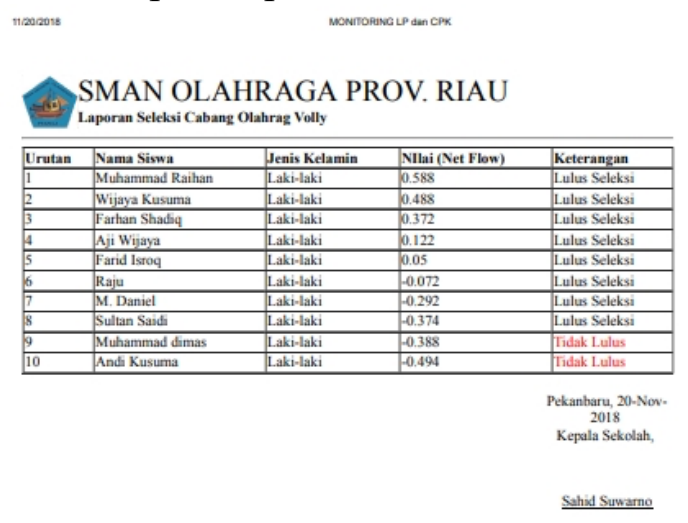

Gambar 12. Halaman Hasil Seleksi Volly Gambar 12 menjelaskan merupakan halaman hasil akhir seleksi cabang olahraga volly, berdasarkan dari nilai siswa cabor volly.

\section{KESIMPULAN}

Hasil dari penelitian yang telah dilakukan, disimpulkan bahwa sistem yang dibangun telah mampu melakukan seleksi cabang olahraga sepak bola, basket maupun volly bagi siswa dan siswi di SMAN Olahraga menggunakan metode promethee. Sistem menampilkan hasil seleksi dengan menghitung net flow. Net flow inilah yang akan menjadi dasar penilaian masuk atau tidaknya siswa tersebut terhadap cabang olahraga yang diikutinya. Semakin tinggi nilai net flow tersebut, maka semakin besar kecocokan siswa terhadap cabang olahraga 
yang dipilih, sehingga siswa dikatakan lulus. Sistem ini membantu pihak sekolah dalam menyeleksi dan menentukan cabang olahraga yang cocok bagi siswa baru.

\section{DAFTAR PUSTAKA}

[1] Yuwono, Bambang, Frans Richard Kodong, Hendy Ayusta Yudha. 2011. "Sistem Pendukung Keputusan Menggunakan Metode Promethee (Studi Kasus : Stasiun Pengisian Bahan Bakar Umum)". Telematika Vol. 8, No. 1, Juli $2011: 63-7$

[2] Taufik, Ichsan, Undang Syaripudin, Jumadi. 2017. "Implementasi Metode Promethee Untuk Menentukan Penerima Beasiswa". Jurnal Istek. Volume X No. 1. ISSN 1979-891

[3] Safrizal dan Lili Tanti. 2015. "Penerapan Metode Promethee Dalam Penyeleksian Siswa Baru (Airlines Staff) Pada LPP Penerbangan".Konferensi Nasional Sistem \& Informatika. STMIK STIKOM Bali

[4] Ubaidi. 2015. "Sistem Pendukung Keputusan Penerimaan Siswa Baru Dengan Metode Promethee (Studi Kasus SD Plus Nurul Hikmah Pamekasan)". Seminar Nasional "Inovasi Dalam Desain Dan Teknologi” - Ideatech 2015 ISSN: 2089-112

[5] Pami, Setya. 2017."Sistem Pendukung Keputusan Pemilihan Karyawan terbaik dengan Metode Promethee" Jurnal Pelita Indonesia, Vol 16 No 3 ISSN 2301-9425

[6] Budiharjo, Harry, Herry Sofyan dan Suparja. "Perencanaan Sistem Pendukung Pengambilan Keputusan Penerimaan Taruna Dengan Metode Promethee (Studi Kasus Seleksi Taruna Akmil)". Seminar Nasional Informatika 2015 (Semnasif 2015) ISSN: 1979-2328. UPN "Veteran" Yogyakarta

[7] Haviluddin, 2011. "Memahami

Penggunaan UML (Unified Modelling

Language"' Jurnal Informatika

Mulawarman. Vol.6 No. 11. 